\title{
Profiles in Medical Courage: John Snow and the Courage of Conviction
}

\author{
Richard A. Robbins, M.D. ${ }^{1}$ \\ Stephen A. Klotz, M.D. ${ }^{2}$ \\ ${ }^{1}$ Phoenix Pulmonary and Critical Care Research and Education Foundation, \\ Gilbert, AZ \\ ${ }^{2}$ Division of Infectious Diseases, University of Arizona, Tucson, AZ
}

\begin{abstract}
The story of John Snow's removal of the handle of the Broad Street pump stopping the London cholera outbreak of 1854 has reached near legendary status. In this review we examine Snow's life and conclude that the removal of the pump handle causing the end of the epidemic is largely myth. However, Snow was a clever man with eclectic medical interests. He not only founded the field of epidemiology but did early pioneering work in resuscitation and anesthesia. It is likely that his self-experimentation with anesthetic gases may have contributed to his early death at age 45 . Largely forgotten during his own time, he is now correctly remembered as a smart physician and scientist with the conviction to pursue what he believed to be right.
\end{abstract}

\section{Introduction}

A poll taken by a UK medical magazine for hospital doctors named John Snow (Figure 1) the greatest physician of all time (1).

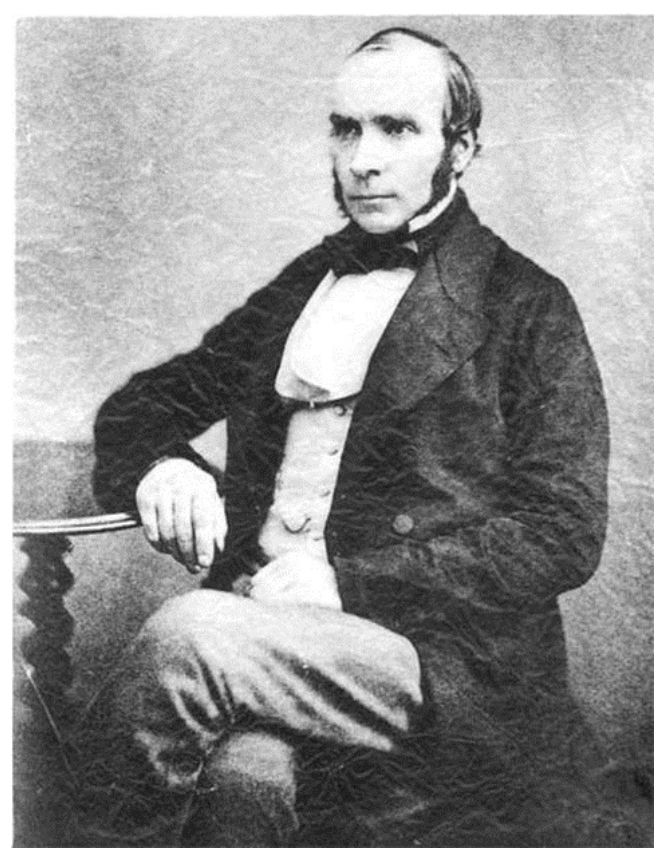

Figure 1. John Snow in 1857. 
Hippocrates was second. However, a recent equally unscientific poll of medical students revealed that none had heard of Snow (Robbins RA, unpublished observations) prompting the writing of this Profile in Medical Courage. Snow's work was largely ignored in his own time (2). The 19th century British medical establishment was in general fiercely opposed to his views on cholera and favored the "miasma" or bad air theory of how cholera was spread $(2,3)$. His somewhat less than friendly personality and early death contributed to his lack of recognition. However, starting in the 1930's with republication of Snow's most famous text, "On the Mode of Communication of Cholera" the story of John Snow and cholera has become a founding chronicle of public health (4). Snow's contributions have been so important that he has been termed the founder of epidemiology (2-4).

Many have heard the famous story of the Broad Street pump and how the removal of the pump handle stopped the cholera epidemic of 1854, although apparently not our medical students. Snow's rise to iconic status originated not only because of his founding the science of epidemiology, but also his pioneering work on resuscitation and anesthesia (2). During his short lifetime, Snow contributed 107 publications to the scientific literature (2). In this review, we examine the life of Snow, his publications and his work on cholera, anesthesia and resuscitation.

\section{Early Years}

John Snow was born into a family of modest means on March 15, 1813 in York, England (2). His father was a laborer in the neighboring coal yard. Beginning about age 6 , Snow attended a private, common day school in York. There were few public schools and common day schools were intended to educate the poor. He attended school until he was 14 and received basic education in reading, writing, arithmetic and the Scriptures. He was noted to be a good student with mathematics and natural history his favorite subjects.

Usually the children of poor families left home as early as possible to earn their own livings. How Snow's family afforded to send him to a private school, even one intended for the poor, remains a mystery. Some suggest that money may have come from his maternal uncle, Charles Empson, a prosperous book merchant first in Newcastle-upon-Tyne and later in Bath (2). However, others suggest Snow's ambitious father, William, was the likely source (2). At about the time he began school, his father began delivering goods by horse-drawn carriage that arrived by river. He saved his money and purchased rental property and eventually a farm. Such upward financial mobility was unusual in $19^{\text {th }}$ century England.

\section{Medical Apprenticeships}


Medical education in the early 1800's was markedly different from today (2). Only two universities, Oxford and Cambridge, granted medical degrees leading to licensure. Snow's modest means meant he could attend neither. The other route to licensure, and the one taken by Snow, was to apprentice with a surgeon and apothecary (pharmacist). Eventually the apprentice could take the licensing test given by the Royal Colleges of Physicians and of Surgeons and the Worshipful Society of Apothecaries to obtain medical licensure.

Snow did 3 apprenticeships beginning at age 14 that lasted 9 years. His first was in Newcastle- upon-Tyne with William Hardcastle, a general practitioner.

Newcastle was 90 miles from York, a fair distance in the first half of the $19^{\text {th }}$ Century. Why Snow was sent so far from home for his first apprenticeship is likely explained by Hardcastle's friendship with Snow's uncle, Charles Empson. Empson was a witness at Hardcastle's wedding and executor of his will. Hardcastle was an established practitioner of good reputation in the Newcastle area who was thirty-one years old at the outset of Snow's apprenticeship.

Snow's apprenticeship with Hardcastle lasted six years. Not only were the foundations of his medical training developed but the first indications of his independent nature became evident. During the third year of his apprenticeship when he was 17 years old, he became a vegetarian and teetotaler. Snow found time to attend classes at what would eventually become a modern medical school. He also developed his interest in cholera. In 1831, when he was 18 years old, Hardcastle sent Snow to provide medical assistance to the local coal miners and their families who were victims of a cholera outbreak. Years later Snow wrote, "That the men [who work in coal pits] are occasionally attacked whilst at work I know, from having seen them brought up from some of the coal-pits ... after having had profuse discharges from the stomach and bowels, and when fast approaching to a state of collapse" (2).

At age 20 Snow went to Burnop Field, a neighboring village near Newcastle and became an assistant to John Watson, a rural apothecary. He apparently had little in common with Mr. Watson and considered his wages very low. He left Burnop Field after only a year and did his next apprenticeship at Pateley Bridge with Joseph Warburton, also a licensed apothecary. Pateley Bridge was and is a small village in a remote region about 30 miles west of York. Snow lived in the large house that served as both home and surgery to Warburton and his family. Snow viewed Warburton with great respect and friendship, later referring to him as his "old master" (2). He remained with Warburton for 18 months.

\section{Formal Medical Education}

At the age of 23 Snow began his formal education by enrolling for a year in the Hunterian School of Medicine located on Great Windmill Street in the Soho region of east London (2). During this time Snow rented an inexpensive room at 11 Bateman's Buildings, a narrow alleyway several blocks north of the Hunterian 
Medical School and just south of Soho Square. In the $19^{\text {th }}$ century Soho could be best described as "dodgy" (5). Respectable families had moved away, and prostitutes, music halls and small theatres had moved in. The Hunterian school was privately run and provided lectures, demonstrations and dissections. Shortly after Snow completed his year at Hunterian, the school closed.

In October 1837 at the age of 24, Snow became a registrar at the Westminster Hospital, thereby gaining experience in a hospital setting (2). The hospital was nearly a mile south of his home on Bateman's Buildings, to which he walked most days. The hospital had been reconstructed and enlarged in 1834, and had a good reputation in surgery. After about 18 months, Snow passed his examination to become a Member of the Royal College of Surgeons of England (MRCS), permitting him to practice general medicine. He ranked 7th among the 114 candidates who passed the examination. Snow also passed his Licentiate of the Society of Apothecaries (LSA), ranking 8th on a list of 10, allowing him to prepare and sell drugs and other medicines. After 12 years of apprenticeship and education he was certified as a general practitioner.

In the mid-1800s, neither the MB nor MD was necessary to practice general medicine. However, Snow's curiosity along with a desire for wealthier, more discerning patients led him to enroll at the newly created University of London Medical School in 1838. While active as a general practitioner, Snow attended the University of London for five years. When he was 30 years old Snow received the Bachelor of Medicine (MB) degree. A year later in December 1844, he obtained the Doctorate of Medicine (or MD), also from the University of London.

\section{Early Practice and Academic Pursuits}

Snow continued his general practice in Soho and was now located at a new address about a block south of Soho Square (2). In 1846 he took a position as lecturer in forensic medicine at the Aldersgate School of Medicine, a private medical school in central London. He remained at the school as Lecturer from 1846 to 1849 when the institution closed for lack of funding. In 1850 he passed the examination to become a Licentiate of the Royal College of Physicians (LRCP) of London. The LRCP was the most elite of the medical profession.

\section{Resuscitation}

Beginning in about 1837, Snow joined the Westminster Medical Society. Although not a particularly sociable man, Snow was able to interact with his medical colleagues and to present his scientific theories. Snow regarded membership in this organization as the most influential in his professional growth (2).

In the 1840's Snow developed an interest in resuscitation. One of the first communications to the Westminster Medical Society described a device for 
resuscitation of the newborn (6). The instrument was based on the concept of the "pulmotor". Snow assumed that the stimulus for respiration, including newborns, was hypoxemia. He also speculated that the pulsive action of the blood was in part due to the capillaries, since it seemed unlikely that heart was sufficiently strong to propel the blood through the arteries, capillaries and veins.

\section{Anesthesia}

Snow's early practice was not particularly successful, at least in part, because he was not very personable (2). During his time at the University of London, Snow became increasingly interested in anesthetics. He conducted numerous experiments, both on animals and himself and invented an improved ether inhaler (2). Air and ether were mixed as vapor at one side of the apparatus and drawn over and round the spiral chamber, to be inhaled by the patient through a mouth-tube fitted with cedarwood ball valves. His work attracted the attention of Robert Liston, the best known surgeon of the day. Liston, who performed the first operation in Europe using ether, was impressed with the difference between the result of anesthesia administered by Snow, and that of less cautious anesthetists. Liston put his ether practice almost entirely into Snow's hands (2). Soon Snow was recognized as the premier anesthetist in London. Although he had practically introduced the use of ether into English surgery, Snow balanced ether against other anaesthetizing agents, particularly chloroform. He administered the later to Queen Victoria during the birth of her last 2 children in 1853 and 1857 (2). Snow published the results of his experience with ether in 1847 , including the definition of four anesthesia stages which continue to be recognized in modern times (7).

\section{Epidemiology and the Broad Street Pump}

By the middle of the 19th century, London along the Thames was a cesspool (Figure 2).

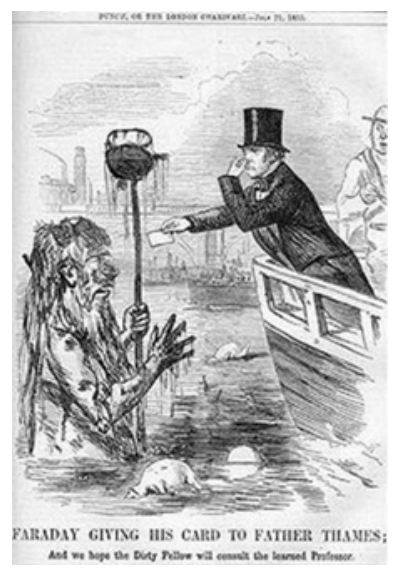

Figure 2. Cartoon of famous English scientist Michael Faraday who wrote a letter to The Times in 1855 complaining of the foul condition of the Thames, which resulted in this cartoon in Punch. 
Both human and animal excrement and garbage were placed in cesspits if not thrown directly into the river. However, the cesspits eventually filled and overflowed draining into the river. Disposal of waste in the river was further complicated in that London is close enough to the North Sea that the river level is affected by the tides. Sewage flowed downriver at low tide but twice a day a wall of water would carry it back upstream. Snow's neighborhood of Soho was especially bad (5). It had become an insanitary place of cow-sheds, slaughterhouses, grease-boiling dens and primitive, decaying sewers.

When cholera first hit England in late 1831, it was thought to be spread by "miasma in the atmosphere" or bad air (2). The cholera outbreaks seemed to occur where the stench was worst, which was often next to water sources. This is hardly surprising since acceptance of the germ theory would wait the discoveries of Pasteur and Koch in the later part of the century (Figure 3).

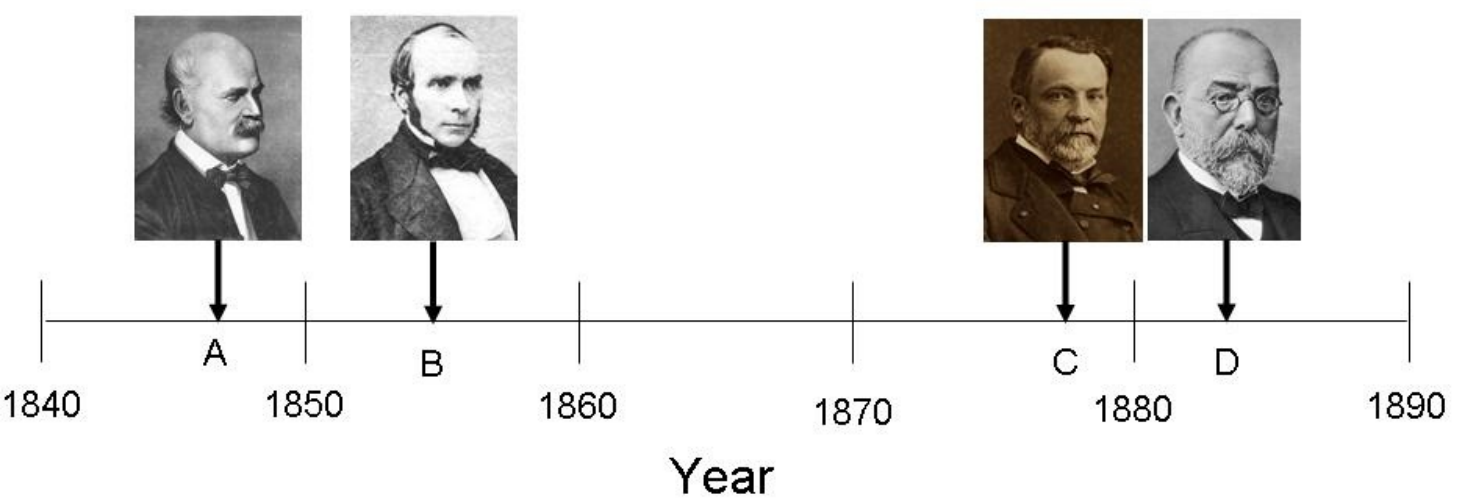

Figure 3. Timeline for some of seminal infectious disease discoveries of the $19^{\text {th }}$ century. A: 1847-Semmelweis discovers that hand washing decreases the incidence of puerperal fever. B: 1855-Snow publishes On the Mode of Communication of Cholera. C: 1878-Pasteur publishes Microbes Organized, Their Role In Fermentation, Putrefaction and the Contagion. D: 1883-Koch identifies the bacterial cause of cholera.

England had suffered numerous cholera outbreaks during the $19^{\text {th }}$ century. Whenever cholera broke out nothing could be done to contain it. The disease rampaged through the industrial cities, leaving tens of thousands dead in its wake. At the beginning of the 1854 London epidemic Soho suffered only a few, isolated cases. However, on the night of August $31^{\text {st }}$ what Dr Snow later called "the most terrible outbreak of cholera which ever occurred in the kingdom" broke out (8). During the next three days, 127 people living in or around Broad Street died. Within a week, most residents had fled their homes, leaving the shops shuttered, the houses locked and the streets deserted. Only those who could not afford to leave remained there. 
By September $10^{\text {th }}$, the number of fatal attacks had reached 500 . Snow's previous researches had convinced him that cholera, "always commences with disturbances of the functions of the alimentary canal" (2). This led him to conclude that it was spread by sewage-tainted water. Snow had traced a recent outbreak in South London to contaminated water supplied by the Southwark and Vauxhall Water Company $(9,10)$. However, no one believed his theory. The water company pooh-poohed his theories and the authorities were reluctant to believe in a theory of fecal-oral contamination.

From the beginning Snow interviewed the families of the victims. His research led him to a pump on the corner of Broad Street and Cambridge Street, at the epicenter of the epidemic. He mapped the deaths of each of the victims (Figure 4).

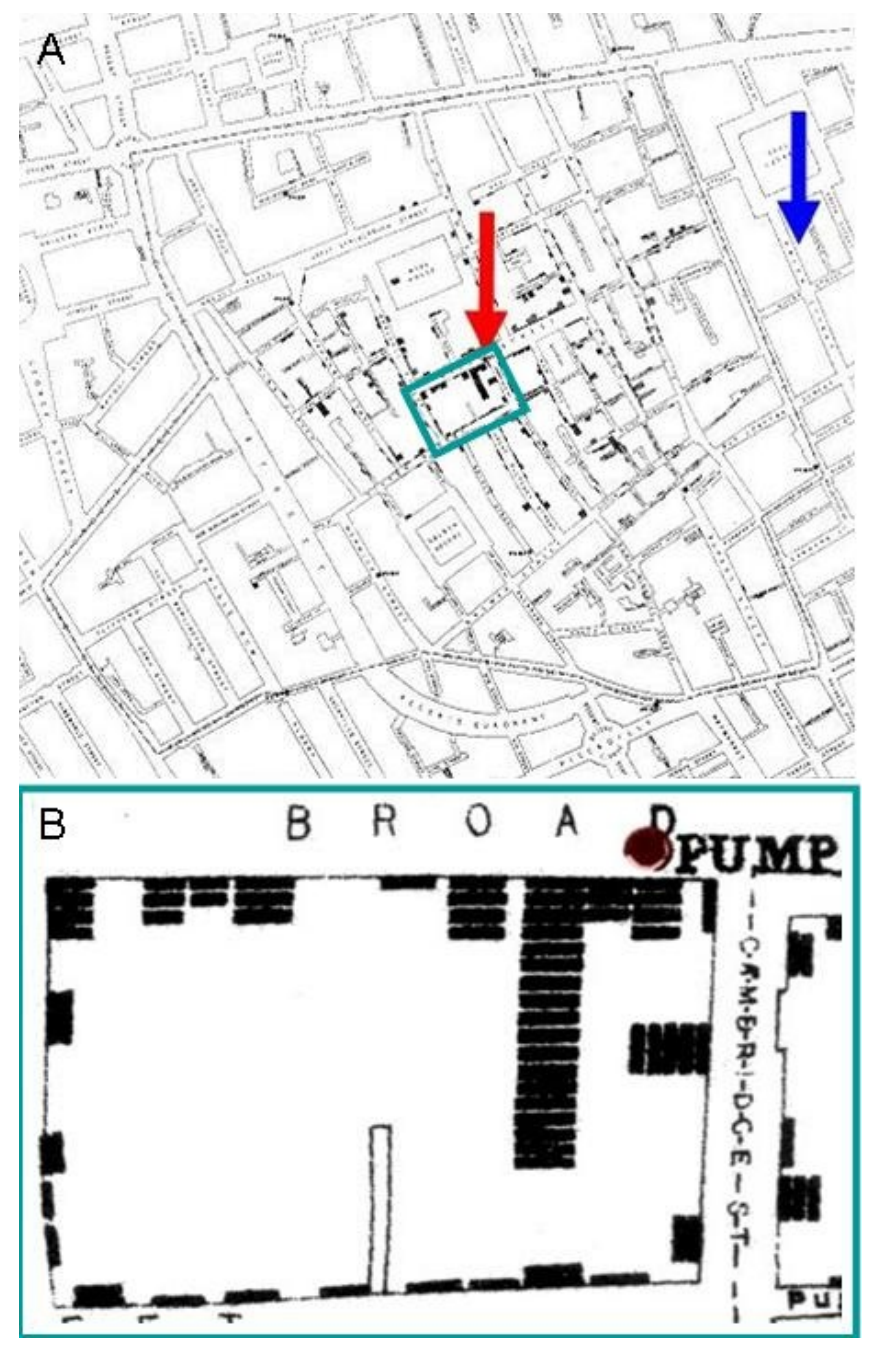

Figure 4. Panel A. Snow's map from his 1855 publication (8). Squares indicate deaths from cholera. The pump is indicated by the red arrow and Snow's residence on Frith Street by the blue arrow (5). Panel B. Enlargement of the green square from Panel A showing the clustering of the deaths surrounding the Broad Street pump. 
Snow would write that " $\ldots$ nearly all the deaths had taken place within a short distance of the pump" (8). He took a sample of water from the pump, and, on examining it under a microscope, found that it contained "white, flocculent particles" (8). By September $7^{\text {th }}$, he was convinced that these were the source of infection.

Snow was a prominent physician and considered somewhat an expert on cholera having published several articles on the disease $(9,10)$. He came uninvited to a meeting of the Board of Guardians of St James's Parish, the region serviced by the Broad Street pump on September $7^{\text {th }}$. In England, the parish is the fundamental tier of local government. Dr. Edwin Lankester, a member of a local group that looked into the causes of the Broad Street outbreak and the first medical officer for the St. James's district, later wrote, "The Board of Guardians met to consult as to what ought to be done. Of that meeting, the late Dr. Snow demanded an audience. He was admitted and gave it as his opinion that the pump in Broad Street, and that pump alone, was the cause of all the pestilence. He was not believed -- not a member of his own profession, not an individual in the parish believed that Snow was right. But the pump was closed nevertheless and the plague was stayed" (2). The pump handle was famously removed.

\section{Aftermath of the 1854 Cholera Outbreak}

By the end of September the outbreak was over leaving 616 residents of Soho dead. However, there were several unexplained deaths from cholera that could not be linked to the Broad Street pump water -- notably, Susannah Eley, a widow living in Hampstead on London's West End, who had died of cholera on September $2^{\text {nd }}$, and her niece who had succumbed the following day (8). Neither of these women had been near Soho. Dr Snow traveled to Hampstead to interview the Eley's son. Snow learned that the widow had once lived on Broad Street, and that she had liked the taste of the well-water there so much that she had sent her servant down to Soho every day to bring back a large bottle for her by cart. The last bottle of had been brought to Hampstead on August $31^{\text {st }}$, at the very start of the epidemic.

Snow's persistence in obtaining as much data as was possible is a remarkable trait demonstrated by the following incidents (8). Only 5 of the 530 inmates of the Poland Street workhouse, which was just around the corner from the pump, contracted cholera. Snow discovered that few drank the pump water, since the workhouse had its own well. Similarly, among the 70 workers in a brewery on Broad Street there were no fatalities at all. It was discovered that the workers were given a beer allowance and never drank from the well.

Snow's "Grand Experiment," compared cholera in the 1854 epidemic in neighborhoods receiving water from two different companies (8). The Lambeth Company delivered water from the upper Thames away from the Broad Street 
pump and urban pollution. On the other hand, the Southwark and Vauxhall Company relied on inlets in the heart of London, where the contamination of water with sewage was common. Snow showed the harmful effect of contaminated water in two nearly equivalent populations, and he suggested intervention strategies to control the epidemic. His ideas and observations, including innovative disease maps, were published in his book On the Mode of Communication of Cholera (8). Later, beginning in the 1930s, Snow's work was republished as a classic work in epidemiology, resulting in his lasting recognition (4).

Snow wrote, "The experiment, too, was on the grandest scale. No fewer than three hundred thousand people of both sexes, of every age and occupation, and of every rank and station, from gentlefolks down to the very poor, were divided into two groups without their choice, and, in most cases, without their knowledge; one group being supplied with water containing the sewage of London, and, amongst it, whatever might have come from the cholera patients, the other group having water quite free from such impurity" (8).

Using a classic $2 \times 2$ set up, Snow obtained data on the two sets of London households and found that during an 1854 epidemic there were 315 deaths from cholera per 10,000 homes among those supplied by Southwark-Vauxhall but only 37 deaths per 10,000 supplied by Lambeth (2). Snow had gotten his numbers from a less than precise Parliamentary report leading to criticism and Snow's own admission that the results were not strong enough to establish that cholera was related to water supply.

Still no one believed Snow. A report by the Board of Health a few months later concluded, "We see no reason to adopt this [Snow's] belief" (2). The pump handle was replaced. However, about a year after the epidemic Snow's theories received support from an unexpected source. The Reverend Henry Whitehead, vicar of St Luke's Church, Berwick Street, did his own investigation (2). Although originally a believer in the miasma theory, Snow's data convinced him that the pump was the source. Furthermore, Whitehead helped Snow to determine the probable cause of the cholera outbreak. Just before the Soho epidemic, a child living at number 40 Broad Street had been taken ill with cholera symptoms. Its diapers had been steeped in water which was subsequently disposed of in a leaking cesspool situated only three feet from the Broad Street well.

Whitehead's findings were published in the architectural journal, The Builder, along with a report on living conditions in Soho (2). "Even in Broad-street it would appear that little has since been done... In St Anne's-Place, and St Anne's-Court, the open cesspools are still to be seen; in the court, so far as we could learn, no change has been made; so that here, in spite of the late numerous deaths, we have all the materials for a fresh epidemic... In some [houses] the water-butts were in deep cellars, close to the undrained cesspool... The overcrowding appears to increase..." The Builder went on to recommend "the immediate 
abandonment and clearing away of all cesspools -- not the disguise of them, but their complete removal".

Nothing was done. The pump handle was replaced. The cesspools were not drained. It was likely "The Great Stink of 1858" that prompted action (11). During the summer warm weather combined with a series of low tides to cause such a stench that Parliament was adjourned for a week. Finally in 1859 the Metropolitan Board of Works, after rejecting many schemes to diminish the Thames' smell, accepted the proposal of Joseph Bazalgette. The intention of this very expensive scheme was to resolve the epidemic of cholera by eliminating the stench (miasma) which was believed to cause it. Over the next six years the main elements of the London sewerage system were created. As an unintended consequence the water supply ceased to be contaminated and resolved the repeated episodes of cholera epidemics.

\section{Later Years and Death}

Snow's health had never been the best. After receiving his MD from the University of London, Snow had suffered from tuberculosis (2). He recovered by spending a good deal of time in the fresh air away from Soho and the Thames. In 1845 he had an acute attack of renal disease. His physician told him to abandon his strict vegetarian diet and to take wine in small quantities. He improved.

Likely of greater significance regarding was his self-experimentation with anesthesia (2). He was the first to carry out experiments on the physiology of anesthesia, and did not spare himself in investigating every possible substance that might be employed as an anesthetic. The pathologic effect of most of these agents was not known in Snow's time.

A clue to the Snow's ill health is a photo showing the swelling of the index finger of his right hand (Figure 5).

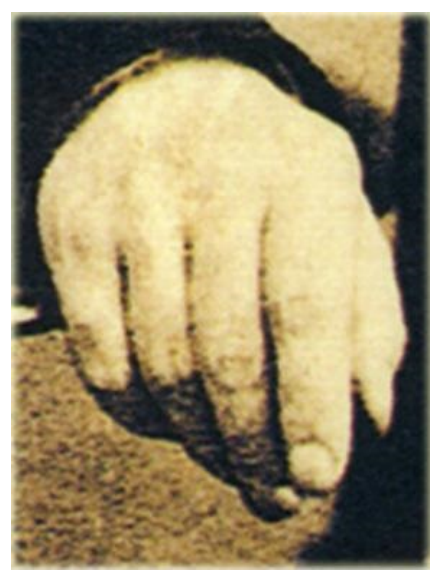

Figure 5. Close up of Snow's right hand taken from Figure 1 showing a swollen index finger. 
Such swelling of the fingers has been associated with chronic renal failure. Exposure to anesthetic gases is now known to have numerous adverse health effects, including severe renal damage. In Snow's case, his swollen fingers were likely due to extensive self-experimentation over nearly a decade with a variety of anesthetic agents.

On the evening of June 9, 1858, John Snow joined a group of colleagues to discuss a new bi-aural (i.e., two ear pieces) stethoscope and the cause of the first Korotkoff sound when measuring blood pressure (2). The next morning, he suffered a slight stroke while working on, "On Chloroform and other Anesthetics". He recovered but a few days later suffered another cerebral accident. His housekeeper found him on the floor. He died a few days later.

At autopsy, Snow's kidneys were found to be "shrunken, granular and encysted" (2). While there was also scar tissue in the kidney from old bouts of tuberculosis, it seems likely that his kidney problems arose from anesthetic experimentation.

On June 26, 1858, the following short notice of death appeared in The Lancet (Figure 6).

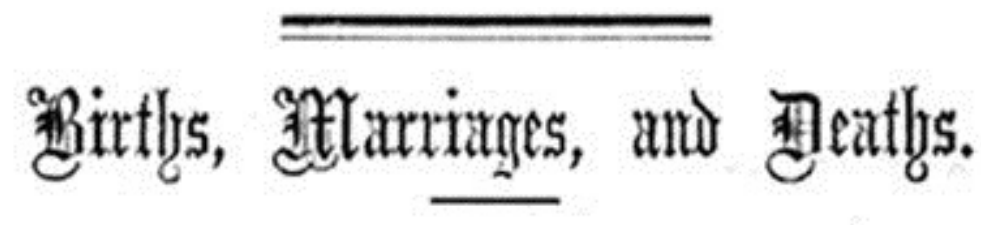

DEATHS.

DR. JoHs SNow.-This well-known physician died at noon on the 16th instant, at his house in Sackville-street, from an attack of apoplexy. His researches on chloroform and other anæsthetics were appreciated by the profession.

Figure 6. Snow's death notice in the Lancet.

A humble obituary for so great a physician.

\section{Legacy}

Snow's work in so many fields is well documented although he was not always right. Snow's life is now commemorated in such an English way-a pub near the original site of the Broad Street pump. The pub was renamed for him in 1955 on the centenary of the Snow's publication of "On the Mode of Communication of Cholera" (Figure 7). 


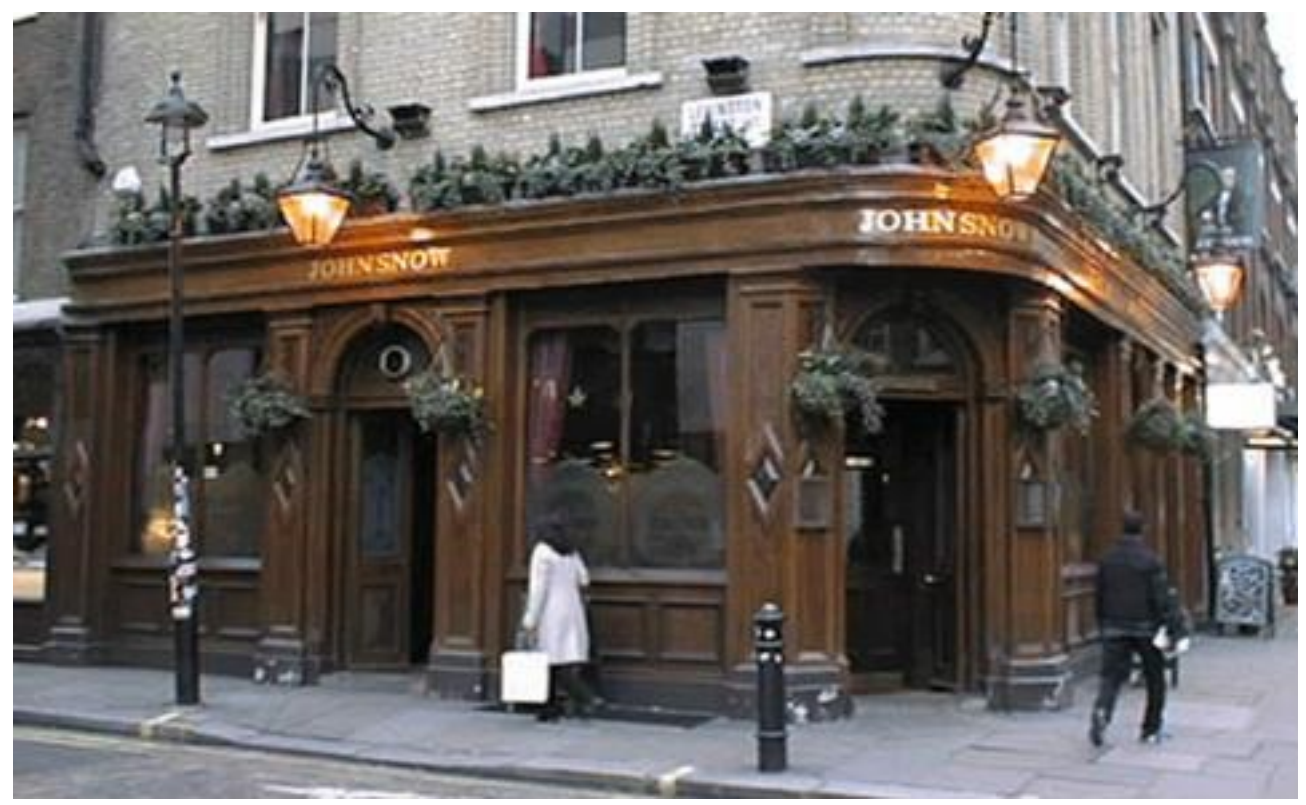

Figure 7. John Snow pub on Broadwick (formerly Broad) Street in modern London.

It is ironic that Snow, who did not drink alcohol or eat meat for most of his life, should be commemorated by a public house where the menu is not vegetarian and the libations are alcoholic.

It is difficult to underestimate the historical importance of Snow's work. Gro Harlem Brundtland, former Director-General of the World Health Organization has said, "In historic terms the marriage between science and health is a relatively recent event. Not long ago superstition, magic and astrology were the only weapons our ancestors had to fight diseases and epidemics that haunted the world. They were seen as divine punishments or unfavorable influence of the heavenly bodies. We owe that marriage to the creators of modern bacteriology, epidemiology and therapeutics - to scientists such as Louis Pasteur, Robert Koch, John Snow, Alexander Fleming and Paul Erlich - and their discoveries that shaped modern medicine and public health policies. They helped rescue our civilization from the dark ages of the unknown - and the unknown had names such as plagues, cholera or syphilis" (2).

When David Satcher, the former Surgeon General, was faced with a complex public health issue, he would frequently ask, "Where is the handle on this Broad Street pump?" (2).

We celebrate Snow for not "caving in" to popular opinion, even against his more illustrious colleagues, a persistence in getting at the truth of the matter, and the courage to put it in print. Yet, his real excellence, lies in his creativity to look at an event as all his contemporaries did and come up with the novel (and correct) solution and his conviction to that solution when he believed he was right. 


\section{References}

1. http://www.ph.ucla.edu/epi/snow.html (accessed 5/7/13).

2. http://www.ph.ucla.edu/epi/snow.html (accessed 5/7/13).

3. http://madisonleighrose.wordpress.com/2012/08/27/john-snow-and-thecholera-myth/ (accessed 5/7/13).

4. Snow J. Snow on Cholera -- A Reprint of Two Papers by John Snow, M.D. together with A Biographical Memoir by B.W. Richardson, M.D., and an Introduction by Wade Hampton Frost, M.D., Hafner Publishing Company, London, 1965.

5. Summers J. Soho -- A History of London's Most Colourful Neighborhood, Bloomsbury, London, 1989, pp. 113-117.

6. Snow J. On asphyxia and on the still-born. London Med Gaz. 1842;1:222-7.

7. Snow J. On the inhalation of the vapour of ether in surgical operations $\mathrm{Br}$. J. Anaesth. 1953;25: 53-4. [CrossRef]

8. Snow J. On the Mode of Communication of Cholera. London: John Churchill, New Burlington Street, England, 1855

9. Snow J. On the pathology and mode of communication of cholera: part 1. London Medical Gazette. 1849;44:745-52.

10. Snow J. On the pathology and mode of communication of cholera: part 2. London Medical Gazette. 1849;44:923-29.

11. http://en.wikipedia.org/wiki/Great Stink (accessed 5/7/13). 